\title{
EVALUATION OF THE AGGRESSIVENESS OF SLOVAK MINERAL WATER SOURCES
}

\author{
Dana VRABLÍKOVÁ ${ }^{1 *}$, Diana PORUBSKÁ ${ }^{1}$, Miriam FENDEKOVÁ ${ }^{1}$, Jarmila BOŽÍKOVÁ ${ }^{2}$ Denisa KÓKAIOVÁ ${ }^{3}$
}

\section{Abstract}

The aggressive properties of natural waters arise due to their specific physical properties and chemical composition. The latest analyses of certified natural and healing mineral water sources according to Act No. 538/2005 were used for the evaluation. A total of 53 sources in 26 localities were evaluated; they comprised 25 sources of bottled natural mineral and healing waters and 28 sources of natural healing waters in 9 spas. The aggressiveness of the water against concrete was weak (17 sources), medium (17 sources), or none (19 sources). The aggressiveness was mostly caused by low $\mathrm{pH}$ values and/or increased $\mathrm{SO}_{4}^{2-}$ content. Their corrosiveness to metal was mostly very high. The results showed that the disintegration of concrete building constructions, well casings and pipelines could occur in most of the evaluated localities in the case of mineral water contacting them. Therefore, preventive measures are necessary.

\section{INTRODUCTION}

Water aggressiveness refers to the ability of water to corrode, i.e., to disintegrate and deteriorate materials that the water is in contact with. All water (rain, surface and groundwater) is corrosive to some degree. However, the specific physical properties and chemical composition of water could accelerate the corrosion. Concrete structures and metal constructions, both surface and subsurface, are examples of materials that could undergo this degradation process.

The corrosive effect of aggressive water is most conspicuous on the front of historical buildings and is caused by acid rain. However, corrosion can also occur due to the contact of surface water and groundwater with concrete building constructions such as roadbeds, bridge decks and substructures, underground car parks or tunnels, and with the metals used for making pipelines that transport water (Volk et al., 2000), including surface and subsurface parts of well
Address

1 Department of Hydrogeology, Faculty of Natural Sciences, Comenius University in Bratislava, Mlynská dolina, 84215 Bratislava, Slovakia

2 Department of Sanitary and Environmental Engineering, Faculty of Civil Engineering, Slovak University of Technology in Bratislava, Radlinského 11, 81368 Bratislava, Slovakia

3 Ministry of Health of the Slovak Republic, Inspectorate of Spas and Springs, Limbová 2, P.O. BOX 52, 83752 Bratislava 37, Slovakia

* Corresponding author: vrablikova@fns.uniba.sk

\section{Key words}

- Concrete and metal constructions,

- water aggressiveness,

- physical properties,

- chemical composition,

- certified natural healing and mineral water sources of Slovakia. casings, storage tanks, metallic plumbing in houses, etc. The specific discussed case is the corrosive influence of seawater on concrete and metal marine structures.

Concrete corrosion could occur as a result of the influence of physical properties or chemical compounds present in the air or water, or as a result of human activities. Concrete corrosion also occurs in soil and rock environments because most building foundations are made of concrete. In this case, the aggressive properties of groundwater could be the reason for the occurrence of corrosion. The main factors causing groundwater aggressiveness are the low amounts of dissolved solids, low $\mathrm{pH}$ values, the presence of aggressive $\mathrm{CO}_{2}$, the high content of sulfates and magnesium or ammonium ions.

The corrosion of metallic pipelines can be caused by many factors, inter alia, the low temporary hardness of water (lack of dissolved calcium bicarbonates and magnesium bicarbonates) or by a high level of sodium, chloride and other ions increasing the electrical conduc- 
tivity of the water. Corrosion can be accelerated by low or high $\mathrm{pH}$ values (Sander at al., 1996), a high flow rate within a pipeline, a high water temperature, the presence of oxygen and dissolved carbon dioxide, the high contents of dissolved solids such as sulfates, the presence of corrosion-related bacteria, and the presence of suspended solids. As a result of metal corrosion, some toxic metals such as lead and copper are released into drinking water. Some toxic metals could cause acute and chronic health problems (Hairston, 1995). An overview of the present state of aggressiveness evaluations in Slovakia was done by Fendeková et al. (2011).

Mineral waters often become sources for the initiation of corrosion processes. The presence of mineral waters with aggressive properties was proved by the construction of water works at Nosice, Liptovská Mara and Klenovec, the operation of the railway station in Zvolen, and a road bed in Banská Bystrica and elsewhere (Hyánková, 1985).

The casings of many hydrogeological wells that tap into mineral waters have been disintegrated by water's corrosive effect, including the BEH-1 well in Bešeňová (Fendek et al., 1988, Fendek 1998, Fendek and Remšík, 2005, Remšík et al., 2005); the same thing could occur with metallic pipelines and the technical equipment of spas and aquaparks. Slovakia is very rich in mineral waters, as documented by Fendek et al. (2002). Therefore the aim of this study was to evaluate the presence of aggressive compounds in natural healing and mineral water sources in Slovakia, which were recognized by Act No. $538 / 2005$.

\section{METHODS AND DATA}

The EU standard EN 206-1 (2002) is used for assessing water aggressiveness. The standard was adopted in the Slovak Republic in 2002 and labelled as STN EN 206-1 (STN 73 2403). Six kinds of aggressive environmental influences were introduced and divided into four degrees. Degree X0 means a non-aggressive effect on the environment; XA1 is weakly aggressive; XA2 is moderately aggressive and XA3 is a strongly aggressive chemical effect on the environment. The limit values are given in Tab. 1.

The content of aggressive $\mathrm{CO}_{2}$ is assessed for a water temperature range from $+5{ }^{\circ} \mathrm{C}$ up to $+25{ }^{\circ} \mathrm{C}$. When two or more chemical parameters reach the same degree of aggressiveness, the next higher degree must be used for characterizing the aggressiveness (STN EN 206-1, 2002).
The corrosive influence of the environment on metallic pipelines was previously assessed in Slovakia by STN 038375 standard "Corrosion protection of underground metallic pipelines." This standard was valid in the former Czechoslovakia since 1986 and adopted for the Slovak Republic since 1.1.1993. Groundwater parameters used for evaluating corrosiveness were the $\mathrm{pH}$ value, the total amount of sulfates and chlorides $\left(\mathrm{SO}_{4}{ }^{2-}+\mathrm{Cl}^{-}\right)$, and the aggressive carbon dioxide $\left(\mathrm{CO}_{2}\right.$ agg. $)$ contents in $\mathrm{mg} / \mathrm{L}$. The standard specified four aggressiveness classes with the aggressiveness of very low (I), medium (II), heightened (III) and very high (IV) degrees. The environmental aggressiveness was assessed according to the most unfavourable value (STN 03 8375, 1990). The standard was cancelled without any substitution as of 1 June 2006 by the decision of the Slovak Standardization Office. The limit values are given in Tab. 2.

Aggressiveness can be caused both naturally and artificially. Groundwater with natural aggressiveness is mostly typical of crystalline and neovolcanic rock complexes, which are characterized by a very low content of dissolved solids, often with low $\mathrm{pH}$ values and an increased content of aggressive carbon dioxide. These properties are connected to a shallow circulation of groundwater, infiltrating rain water properties, a rock environment with prevailing low-reactive silica minerals, and the presence of deep tectonic lines that feed groundwater with carbon dioxide. In many places, sulfidic ore deposits are present in this type of rock environment as the source of very high concentrations of sulfates - the product of the oxidation of sulfides. Aggressive groundwater could also occur in sandstones of flysch rocks and very often in carbonatic rocks bearing deep-circulation mineral waters with a high content of dissolved carbon dioxide.

The human-induced sources of water aggressiveness are mostly industrial waters with heightened concentrations of sulfates and occasionally also magnesium ions.

Mineral waters with their chemical composition often have aggressive properties affecting the rock environment where they are circulating and stored, and also the environment where the technical structures of spas and bottling sites are located.

There are 75 sources of mineral water with a water temperature below $25^{\circ} \mathrm{C}$ (for which the limit values of the technical STN EN 2061 standard are valid) and which have been recognized by the Ministry of Health of the Slovak Republic for natural healing or natural mineral waters according to Act No. 538/2005. This Act provides for the recognition of natural healing waters, and natural mineral waters, the use and protection of natural healing springs and natural mineral springs, the recognition of climatic conditions suitable for healing and their

Tab. 1 Limit values for groundwater properties chemically affecting concrete according to STN EN 206-1.

\begin{tabular}{|l|c|c|c|}
\hline Chemical characteristics & \multicolumn{3}{|c|}{ STN EN 206-1- degree of influence } \\
\hline & XA1 (weakly aggressive) & XA2 (moderately aggressive) & XA3 (strongly aggressive) \\
\hline $\mathrm{pH}$ & $\leq 6.5$ and $\geq 5.5$ & $<5.5$ and $\geq 4.5$ & $<4.5$ and $\geq 4.0$ \\
\hline Aggressive CO2 mg/L & $\geq 15$ and $\leq 40$ & $>40$ and $\leq 100$ & $>100$ up to saturation \\
\hline $\mathrm{Mg}^{2+} \mathrm{mg} / \mathrm{L}$ & $\geq 300$ and $\leq 1000$ & $>1000$ and $\leq 3000$ & $>3000$ up to saturation \\
\hline $\mathrm{NH}_{4}^{+} \mathrm{mg} / \mathrm{L}$ & $\geq 15$ and $\leq 30$ & $>30$ and $\leq 60$ & $>60$ and $\leq 100$ \\
\hline $\mathrm{SO}_{4}^{2-} \mathrm{mg} / \mathrm{L}$ & $\geq 200$ and $\leq 600$ & $>600$ and $\leq 3000$ & $>3000$ and $\leq 6000$ \\
\hline
\end{tabular}

Tab. 2 Limit values for groundwater properties affecting steel according to STN 038375.

\begin{tabular}{|l|c|c|c|}
\hline Environment aggressiveness & $\mathrm{pH}$ value & $\mathrm{SO}_{4}{ }^{2-}+\mathrm{Cl}^{-} \mathrm{mg} / \mathrm{L}$ & Aggressive $\mathrm{CO}_{2} \mathrm{mg}^{\mathrm{L}}$ \\
\hline Very low I & 6.5 up to 5.5 & $<100$ & 0 \\
\hline Medium II & 8.5 up to 14 & 100 up to 200 & 0 \\
\hline Heightened III & 6.0 up to 6.5 & 200 up to 300 & 5 \\
\hline Very high IV & $<6.0$ & $>300$ & 5 \\
\hline
\end{tabular}


protection, the conditions of authorisation for maintaining natural healing spas and medical spa institutions, the conditions for recognition of spa sites, the protection of spa areas and requirements for spa areas, the rights and duties of physical and juridical persons in the recognition of natural healing waters, and natural mineral waters, the climatic conditions suitable for healing and during its use, the force of governmental bodies and municipalities, and the responsibility for breaking the rules stated by this act.

A total of 19 natural mineral water sources (PMZ) and seven natural healing water sources (PLZ) are bottled in Slovakia; 23 natural healing water sources are used for indoor and outdoor balneotherapy. The natural healing water source Ondrej (BC-1) in Brusno belongs to two categories (bottled and used for balneotherapy). Another five sources (Brusno - source of Ďumbier; Sliač - sources of Štefánik, Bystrica, Adam and Lenkey) are used for drinking purposes by the public. The rest of the recognized mineral water sources are used as monitoring objects without any other utilization at the moment.

The latest chemical analyses of mineral water were used in the study. A total of 53 sources of mineral waters utilized in 26 localities (Tab. 3 and 4) were assessed, from which 25 sources of natu- ral mineral and natural healing water sources are bottled (Baldovce, Brusno, Budiš, Cigel'ka, Čačín, Kláštor pod Znievom, Korytnica, Lipovce, Lúka, Martin, Maštinec, Nová Lubovňa, Santovka, Slatina, Sulín, Tornal'a and Trenčianske Mitice). The rest, i.e., 28 evaluated sources of natural healing waters (23 used for balneotherapy and five for drinking by the public), are situated in spas as follows: Bardejovské kúpele, Brusno, Červený Kláštor, Č́íž, Nimnica, Piešt'any, Sliač, Smrdáky, and Vyšné Ružbachy.

The concentration of aggressive carbon dioxide is not measured for the needs of the Inspectorate of Spas and Springs. Therefore, the probable presence of aggressive $\mathrm{CO}_{2}$ in natural and healing mineral waters was evaluated based on concentrations of aggressive carbon dioxide in the natural mineral springs of the surrounding areas (Rapant et al., 1996). A total of 13 natural springs were coordinated with 10 localities with certified mineral water and natural healing water sources and evaluated according to STN EN 206-1 and STN 03 8375 as follows: Číž (three sources - Č́í̌, Rimavská Seč and Zádor), Martin (two sources - Martin-Záturčie and Košúty), Bardejovské kúpele (Zborov), Čačín (Dolná Mičiná), Baldovce, Pieštany, Slatina, Smrdáky, Tornal'a and Trenčianske Mitice (Trenčianske Jastrabie).

Tab. 3 Aggressiveness parameters of bottled natural mineral and healing water sources.

\begin{tabular}{|c|c|c|c|c|c|c|c|c|c|c|c|}
\hline \multirow[b]{2}{*}{ Locality } & \multirow{2}{*}{$\begin{array}{l}\text { Source } \\
\text { (name and } \\
\text { labelling) }\end{array}$} & \multirow[b]{2}{*}{$\mathrm{M}(\mathrm{mg} / \mathrm{L})$} & \multicolumn{6}{|c|}{ Aggressive effect on concrete } & \multicolumn{3}{|c|}{ Aggressive effect on steel } \\
\hline & & & $\begin{array}{c}\mathrm{SO}_{4}^{2-} \\
(\mathrm{mg} / \mathrm{L})\end{array}$ & $\mathrm{pH}$ & $\begin{array}{c}\mathrm{NH}_{4}^{+} \\
(\mathrm{mg} / \mathrm{L})\end{array}$ & $\begin{array}{c}\mathrm{Mg}^{2+} \\
(\mathrm{mg} / \mathrm{L})\end{array}$ & \begin{tabular}{|c|}
$\mathrm{T}_{\mathrm{v}}$ \\
$\left({ }^{\circ} \mathrm{C}\right)$ \\
\end{tabular} & degree & $\mathrm{pH}$ & $\mathrm{SO}_{4}^{2-}+\mathrm{Cl}^{-}(\mathrm{mg} / \mathrm{L})$ & degree \\
\hline Baldovce PMZ & Deák, BV-1 & 2037 & 171 & $\underline{6.29}$ & 0.67 & 70.05 & 10.4 & XA1 & 6.29 & $171+56=227$ & III \\
\hline Baldovce PMZ & Polux, B-4A & 3662 & $\underline{444}$ & $\underline{6.29}$ & 0.79 & 149.5 & 13.4 & $\mathrm{XA2}$ & 6.29 & $444+123=567$ & IV \\
\hline Brusno PLZ & Ondrej, BC-1 & 1828.5 & $\underline{551}$ & 6.6 & 0.31 & 87.49 & 18.5 & XA1 & $\underline{6.6}$ & $551+37.47=588.47$ & IV \\
\hline Budiš PMZ & B-5 & 1925.5 & $\underline{297}$ & $\underline{6.17}$ & 0.33 & 37.45 & 11.8 & XA2 & 6.17 & $297+17=314$ & IV \\
\hline Budiš PMZ & B-6 & 2385 & $\underline{355}$ & $\underline{6.17}$ & 0.31 & 45 & 13.0 & XA2 & 6.17 & $355+23.4=378.4$ & IV \\
\hline Cigel'ka PLZ & $\mathrm{CH}-1$ & 29354.5 & 13.8 & 7.35 & 12.4 & 74 & 9.4 & $\mathrm{x} 0$ & $\underline{7.35}$ & $13.8+3530=3543.8$ & IV \\
\hline Čačín PMZ & ČAM-1 & 1988.5 & 1.825 & $\underline{6.37}$ & 0.065 & 69 & 15.7 & XA1 & 6.37 & $\underline{1.825+3.9=5.725}$ & III \\
\hline Kláštor p. Znievom PMZ & KM-1 & 1870.5 & 92.2 & 6.69 & 6.32 & 73.9 & 16.1 & xo & $\underline{6.69}$ & $92.2+11.7=103.9$ & $\|$ \\
\hline Korytnica I PLZ & Klement, S-7 & 3231 & 1300 & 5.93 & 0.035 & 186 & 9.8 & XA2 & 5.93 & $1300+4.61=1304.61$ & IV \\
\hline Korytnica I PLZ & $\begin{array}{l}\text { Antonín, } \\
\text { S-2 (PMZ) }\end{array}$ & 3463 & 1355 & $\underline{6.01}$ & 0.35 & 179 & 9.0 & XA2 & 6.01 & $1355+6.03=1361.03$ & IV \\
\hline Korytnica II PLZ & HKV-2, Fedorka & 2138 & 1300 & 7.48 & 0.02 & 162.5 & 7.8 & XA2 & $\underline{7.48}$ & $1300+3.55=1303.55$ & IV \\
\hline Lipovce PMZ & $\begin{array}{c}\text { Salvator I, } \\
\text { Cifrovaný, S -1 }\end{array}$ & 3143 & 117.5 & $\underline{6.4}$ & 0.76 & 142 & 12.5 & XA1 & 6.4 & $117.5+18.3=135.8$ & III \\
\hline Lipovce PMZ & Salvator II, S-2 & 3850 & 145.5 & 6.56 & 0.94 & 179 & 16.0 & $\mathrm{X} 0$ & $\underline{6.56}$ & $145.5+122=267.5$ & III \\
\hline Lúka PMZ & $\begin{array}{c}\text { Matúšov } \\
\text { prameň, CC-1 }\end{array}$ & 510.5 & 18.05 & 7.32 & 0.05 & 37.75 & 11.6 & X0 & $\underline{7.32}$ & $18.05+3.05=21.1$ & I \\
\hline Martin PMZ & $\begin{array}{l}\text { Fatra II, } \\
\text { BJ-2 }\end{array}$ & 2656.5 & 107.5 & 7.03 & 29.6 & 47.65 & 12.1 & $\mathrm{X} 0$ & $\underline{7.03}$ & $107.5+37.25=144.75$ & II \\
\hline Martin PLZ & BJ-4 & 7534 & 307.5 & 6.71 & 56.8 & 125.5 & 14.0 & XA1 & $\underline{6.71}$ & $307.5+68.45=375.95$ & IV \\
\hline Maštinec PMZ & ST-1, Grácia & 178 & 14.1 & 4.72 & 0.02 & 6.2 & 9.8 & XA2 & 4.72 & $14.1+25=39.1$ & IV \\
\hline Maštinec PMZ & $\mathrm{HM}-1$ & 149 & 18.35 & 4.69 & 0.085 & 6.69 & 11.2 & XA2 & 4.69 & $\underline{18.35+13.85=32.2}$ & IV \\
\hline Nová L’ubovňa PMZ & LZ-6, Veronika & 2491.5 & 12.15 & 6.63 & 2.7 & 176.97 & 9.6 & $\mathrm{x} 0$ & $\underline{6.63}$ & $12.15+10.82=22.97$ & $\mathrm{I}$ \\
\hline Santovka PMZ & Santovka I, B-6 & 3241 & $\underline{353.5}$ & $\underline{6.43}$ & 0.53 & 67.1 & 15 & XA2 & 6.43 & $353.5+194=547.5$ & IV \\
\hline Slatina PMZ & BB-2 & 1874 & $\underline{231}$ & 6.32 & 0.89 & 53.75 & 14.4 & XA2 & 6.32 & $231+190=421$ & IV \\
\hline Sulín PLZ & MS-1, Johanus & 5587.5 & 14 & 6.77 & 2.83 & 267.77 & 7.8 & $\mathrm{X} 0$ & $\underline{6.77}$ & $\underline{14+50.11=64.11}$ & I \\
\hline Tornal'a PMZ & HVŠ-1 & 2934 & $\underline{360.5}$ & $\underline{6.35}$ & 1.45 & 145 & 16.6 & XA2 & 6.35 & $360.5+36.9=397.4$ & IV \\
\hline Tornal'a PMZ & ŠB-12 & 2949.5 & $\underline{376}$ & $\underline{6.37}$ & 1.47 & 141.5 & 17.4 & XA2 & 6.37 & $376+37.6=413.6$ & IV \\
\hline Trenčianske Mitice PMZ & MP-1 & 1559 & 22.65 & 6.15 & 0.05 & 79 & 11.5 & XA1 & 6.15 & $22.65+21.5=44.15$ & III \\
\hline
\end{tabular}




\section{RESULTS}

The mineral waters in all the mentioned localities were evaluated according to their aggressive effect on concrete constructions (STN EN $206-1$ ) and on steel pipelines (STN 03 8375). The results of the evaluation of the natural mineral sources (PMZ) and bottled natural healing sources (PLZ) are in Tab. 3; the results for the natural healing water sources (PLZ) are in Tab. 4. The values of the total dissolved solids $(\mathrm{M}, \mathrm{mg} / \mathrm{L})$ and water temperature $\left(\mathrm{T}_{\mathrm{v}},{ }^{\circ} \mathrm{C}\right)$ are also given in both tables. Weakly aggressive environments for concrete constructions (XA1) and very low aggressiveness for steel (I) are given by the underlined numbers; the moderately aggressive environments for concrete (XA2) and medium aggressiveness for steel (II) are given by the bold numbers. The heightened aggressiveness for steel (III) is given in italics, and the very high aggressiveness for steel (IV) is given by the italic and bold numbers. The concentrations of $\mathrm{SO}_{4}^{2-}$ and $\mathrm{Cl}^{-}$anions are given in Tabs. 3 and 4 and labelled as $\mathrm{SO}_{4}^{2-}+\mathrm{Cl}^{-}$, together with the total of both of them in the second row.

The natural mineral and healing waters in the Cigel'ka, Kláštor pod Znievom, Lúka, Nová Lubovňa and Sulín localities do not aggressively affect concrete constructions.

Waters in the rest of the localities have aggressive properties. The increased contents of sulfates together with the low $\mathrm{pH}$ values are the reasons for the aggressiveness of the mineral water in Baldovce, Budiš, Korytnica, Santovka, Slatina and Tornal'a. In Brusno and Martin, only sulfate aggressiveness was found; in Čačín, Lipovce, Maštinec and Trenčianske Mitice, only low $\mathrm{pH}$ values occurred. The mineral water has a weak degree of aggressiveness (XA1) in all the cases except for the sources in Maštinec (HM-1) and Korytnica (Antonín, HKV-2), where moderately aggressive water (degree XA2) is present.

The sources of the natural healing waters in the spas of Nimnica (2 sources, Tab. 4), Smrdáky (two sources, Tab. 4) and Bardejovské kúpele (five sources, Tab. 4) do not create risks for concrete constructions. Concrete constructions can be affected by the 4 sources of the Bardejovské kúpele spa due to the low $\mathrm{pH}$ values. The natural healing waters in Brusno are aggressive either because of increased concentrations of sulfates (two sources) or because of increased sulfate concentrations together with low $\mathrm{pH}$ values (one source). The source in Sliač has a low $\mathrm{pH}$ value; the sources in the spas of Červený Kláštor, Pieštany and Vyšné Ružbachy are aggressive because of the increased concentrations of sulfates. Water aggressiveness due to increased concentrations of magnesium was found in only one source, i.e., Č́žz. The degree of aggressiveness was the lowest, i.e., weak (XA1), in all the spas except for Sliač, where moderately aggressive (XA2) natural healing waters occur.

Tab. 4 Aggressiveness parameters of natural healing water sources.

\begin{tabular}{|c|c|c|c|c|c|c|c|c|c|c|c|}
\hline \multirow[b]{2}{*}{ Locality } & \multirow{2}{*}{$\begin{array}{c}\text { Source } \\
\text { (name and } \\
\text { labelling) }\end{array}$} & \multirow{2}{*}{$\begin{array}{c}\mathrm{M} \\
(\mathrm{mg} / \mathrm{L})\end{array}$} & \multicolumn{6}{|c|}{ Aggressive effect on concrete } & \multicolumn{3}{|c|}{ Aggressive effect on steel } \\
\hline & & & \begin{tabular}{|c|}
$\mathrm{SO}_{4}^{2-}$ \\
$(\mathrm{mg} / \mathrm{L})$
\end{tabular} & $\mathrm{pH}$ & $\begin{array}{c}\mathrm{NH}_{4}^{+} \\
(\mathrm{mg} / \mathrm{L})\end{array}$ & $\begin{array}{c}\mathrm{Mg}^{2+} \\
(\mathrm{mg} / \mathrm{L})\end{array}$ & $\mathrm{T}_{\mathrm{v}}\left({ }^{\circ} \mathrm{C}\right)$ & degree & $\mathrm{pH}$ & $\mathrm{SO}_{4}{ }^{2-}+\mathrm{Cl}^{-}(\mathrm{mg} / \mathrm{L})$ & degree \\
\hline Baldovce PMZ & Deák, BV-1 & 2037 & 171 & $\underline{6.29}$ & 0.67 & 70.05 & 10.4 & XA1 & 6.29 & $171+56=227$ & III \\
\hline Baldovce PMZ & Polux, B-4A & 3662 & $\underline{444}$ & $\underline{6.29}$ & 0.79 & 149.5 & 13.4 & $\mathrm{XA2}$ & 6.29 & $444+123=567$ & IV \\
\hline Brusno PLZ & Ondrej, BC-1 & 1828.5 & $\underline{551}$ & 6.6 & 0.31 & 87.49 & 18.5 & XA1 & $\underline{6.6}$ & $551+37.47=588.47$ & IV \\
\hline Budiš PMZ & B-5 & 1925.5 & $\underline{297}$ & $\underline{6.17}$ & 0.33 & 37.45 & 11.8 & $\mathrm{XA2}$ & 6.17 & $297+17=314$ & IV \\
\hline Budiš PMZ & B-6 & 2385 & $\underline{355}$ & $\underline{6.17}$ & 0.31 & 45 & 13.0 & XA2 & 6.17 & $355+23.4=378.4$ & IV \\
\hline Cigel'ka PLZ & $\mathrm{CH}-1$ & 29354.5 & 13.8 & 7.35 & 12.4 & 74 & 9.4 & $\mathrm{X} 0$ & $\underline{7.35}$ & $13.8+3530=3543.8$ & IV \\
\hline Čačín PMZ & ČAM-1 & 1988.5 & 1.825 & $\underline{6.37}$ & 0.065 & 69 & 15.7 & $\mathrm{XA1}$ & 6.37 & $1.825+3.9=5.725$ & III \\
\hline Kláštor p. Znievom PMZ & KM-1 & 1870.5 & 92.2 & 6.69 & 6.32 & 73.9 & 16.1 & $\mathrm{x} 0$ & $\underline{6.69}$ & $92.2+11.7=103.9$ & II \\
\hline Korytnica I PLZ & Klement, S-7 & 3231 & $\underline{1300}$ & $\underline{5.93}$ & 0.035 & 186 & 9.8 & XA2 & 5.93 & $1300+4.61=1304.61$ & IV \\
\hline Korytnica I PLZ & $\begin{array}{c}\text { Antonín, S-2 } \\
\text { (PMZ) }\end{array}$ & 3463 & 1355 & $\underline{6.01}$ & 0.35 & 179 & 9.0 & XA2 & 6.01 & $1355+6.03=1361.03$ & IV \\
\hline Korytnica II PLZ & HKV-2, Fedorka & 2138 & 1300 & 7.48 & 0.02 & 162.5 & 7.8 & XA2 & $\underline{7.48}$ & $1300+3.55=1303.55$ & IV \\
\hline Lipovce PMZ & \begin{tabular}{|c|} 
Salvator I, \\
Cifrovaný, S-1 \\
\end{tabular} & 3143 & 117.5 & $\underline{6.4}$ & 0.76 & 142 & 12.5 & XA1 & 6.4 & $117.5+18.3=135.8$ & III \\
\hline Lipovce PMZ & Salvator II, S-2 & 3850 & 145.5 & 6.56 & 0.94 & 179 & 16.0 & $\mathrm{X} 0$ & $\underline{6.56}$ & $145.5+122=267.5$ & III \\
\hline Lúka PMZ & $\begin{array}{c}\text { Matúšov } \\
\text { prameň, CC-1 }\end{array}$ & 510.5 & 18.05 & 7.32 & 0.05 & 37.75 & 11.6 & $\mathrm{X} 0$ & $\underline{7.32}$ & $18.05+3.05=21.1$ & I \\
\hline Martin PMZ & Fatra II, BJ-2 & 2656.5 & 107.5 & 7.03 & 29.6 & 47.65 & 12.1 & $\mathrm{X} 0$ & $\underline{7.03}$ & $107.5+37.25=144.75$ & II \\
\hline Martin PLZ & BJ-4 & 7534 & 307.5 & 6.71 & 56.8 & 125.5 & 14.0 & XA1 & $\underline{6.71}$ & $307.5+68.45=375.95$ & IV \\
\hline Maštinec PMZ & ST-1, Grácia & 178 & 14.1 & $\underline{4.72}$ & 0.02 & 6.2 & 9.8 & XA2 & 4.72 & $14.1+25=39.1$ & IV \\
\hline Maštinec PMZ & $\mathrm{HM}-1$ & 149 & 18.35 & 4.69 & 0.085 & 6.69 & 11.2 & XA2 & 4.69 & $\underline{18.35+13.85=32.2}$ & IV \\
\hline Nová Ĺubovňa PMZ & LZ-6, Veronika & 2491.5 & 12.15 & 6.63 & 2.7 & 176.97 & 9.6 & $\mathrm{X} 0$ & $\underline{6.63}$ & $\underline{12.15+10.82=22.97}$ & I \\
\hline Santovka PMZ & Santovka I, B-6 & 3241 & 353.5 & $\underline{6.43}$ & 0.53 & 67.1 & 15 & XA2 & 6.43 & $353.5+194=547.5$ & IV \\
\hline Slatina PMZ & BB-2 & 1874 & $\underline{231}$ & $\underline{6.32}$ & 0.89 & 53.75 & 14.4 & XA2 & 6.32 & $231+190=421$ & IV \\
\hline Sulín PLZ & MS-1, Johanus & 5587.5 & w14 & 6.77 & 2.83 & 267.77 & 7.8 & $\mathrm{x} 0$ & $\underline{6.77}$ & $\underline{14+50.11=64.11}$ & $\mathrm{I}$ \\
\hline Tornal'a PMZ & HVŠ-1 & 2934 & $\underline{360.5}$ & $\underline{6.35}$ & 1.45 & 145 & 16.6 & XA2 & 6.35 & $360.5+36.9=397.4$ & IV \\
\hline Tornal'a PMZ & ŠB-12 & 2949.5 & $\underline{376}$ & $\underline{6.37}$ & 1.47 & 141.5 & 17.4 & XA2 & 6.37 & $376+37.6=413.6$ & IV \\
\hline Trenčianske Mitice PMZ & MP-1 & 1559 & 22.65 & $\underline{6.15}$ & 0.05 & 79 & 11.5 & XA1 & 6.15 & $\underline{22.65+21.5=44.15}$ & III \\
\hline
\end{tabular}


Despite the fact that the Slovak technical STN 038375 standard has already been cancelled, an assessment of the aggressive effect of mineral water sources on metallic pipelines was done. It showed that all the mineral water sources have aggressive properties. A very low degree of aggressiveness (degree I) was found in the mineral water sources and bottled healing water sources in Sulín, Nová Lubovňa and Lúka. A moderate degree of aggressiveness (II) is in the Kláštor pod Znievom and Fatra II - BJ-2 sources in Martin. Heightened aggressiveness (III) is present at the Trenčianske Mitice, Lipovce, Čačín and Deák sources in Baldovce. The rest of the natural mineral and healing water sources have a very high degree of aggressiveness (IV) towards metal constructions. The aggressiveness is mostly caused by the total content of sulfate and chloride anions; only the sources in Maštinec, Čačín, Lipovce and Trenčianske Mitice have corrosive properties caused by low $\mathrm{pH}$ values.

Natural healing waters in spas have aggressive properties in the highest degree (IV) in almost all the localities. The exceptions are the Alexander source in Bardejovské kúpele and the B-9 source in Nimnica, where the degree of aggressiveness is very low (I), and two other sources in Bardejovské kúpele (Anna and Klára), where a medium degree of aggressiveness (II) is present. The source of the aggressiveness is mostly caused by the total amount of $\mathrm{SO}_{4}^{2-}+\mathrm{Cl}^{-}$; in one source in Sliač and one in Bardejovské kúpele, the aggressiveness is caused by the $\mathrm{pH}$ values.

In order to evaluate the aggressiveness caused by the presence of aggressive carbon dioxide, 13 mineral springs in the vicinity of the recognized mineral water and natural healing water sources were assessed. None of the sources had aggressiveness caused by aggressive carbon dioxide. Four springs (Baldovce, the surroundings of Bardejovské kúpele, the surroundings of Čačín and Smrdáky) were not aggressive towards concrete at all; the rest of them (nine springs) were aggressive in the lowest degree (XA1) because of the increased concentration of sulfate anions.

As to the aggressiveness towards steel, there was only one source in Tornal'a with a very high degree of aggressiveness caused by the presence of carbon dioxide.
Generally, a very low degree of aggressiveness was documented in the spring water situated close to Bardejovské kúpele (in Zborov) and close to Čačín (in Dolná Mičiná). A medium degree was found in Baldovce, and a heightened degree in Piešt'any, which is close to Martin (Košúty) and in Smrdáky. A very high degree of aggressiveness of the water was estimated for the sources in Ćíž and its surroundings (Rimavská Seč and Zádor), in Slatina, Tornal'a, close to Trenčianske Mitice (Trenčianske Jastrabie), and in Martin (Martin-Záturčie). The high total content of $\mathrm{SO}_{4}{ }^{2-}+\mathrm{Cl}^{-}$was mostly the source of the aggressiveness. The sources in Zborov and Dolná Mičiná had a very low degree of aggressiveness caused by all the evaluated factors. An overview of the aggressive properties of the mineral springs coordinated with the certified mineral water and natural healing water sources is in Tab. 5.

The map of the location of all the evaluated sources of mineral water and natural healing water sources is in Fig. 1.

\section{CONCLUSION}

The assessment of the aggressive properties of water in the certified sources of bottled mineral waters showed that except for a few of them (Cigel'ka CH-1, Kláštor pod Znievom KM-1, Lipovce Salvator II and Lúka CC-1), all these sources are aggressive towards concrete in the XA1 degree and, in the case of the Korytnica I, Korytnica II and Maštinec HM-1 sources, even in the XA2 degree. The reason for the aggressive effects is the under-limit value of the $\mathrm{pH}$ in the 15 sources, and the over-limit concentrations of sulfates in 12 sources. In nine sources both factors were combined. Aggressiveness caused by over-limit concentrations of ammonium ions was not found. The mineral water in all the sources is aggressive towards metal materials. Degree I was estimated in three sources, degree II in two sources, degree III in five sources, and degree IV in 15 sources. The main reason for the aggressiveness of mineral water towards metals is the high total concentration of sulfate and chloride anions together with the low $\mathrm{pH}$ values.

Tab. 5 Aggressiveness parameters of mineral springs from the database of the Geochemical atlas-Groundwater part (Rapant et al., 1996).

\begin{tabular}{|c|c|c|c|c|c|c|c|c|c|c|c|c|c|}
\hline \multirow[b]{2}{*}{ Locality } & \multirow{2}{*}{$\begin{array}{l}\text { Recognized } \\
\text { PLZ/PMZ }\end{array}$} & \multirow{2}{*}{$\begin{array}{c}\mathrm{T}_{\mathrm{v}} \\
\left({ }^{\circ} \mathrm{C}\right)\end{array}$} & \multirow{2}{*}{$\begin{array}{c}M \\
(m g / L)\end{array}$} & \multicolumn{6}{|c|}{ Aggressive effect on concrete } & \multicolumn{4}{|c|}{ Aggressive effect on steel } \\
\hline & & & & $\begin{array}{c}\mathrm{SO}_{4}^{2-} \\
(\mathrm{mg} / \mathrm{L})\end{array}$ & $\mathrm{pH}$ & \begin{tabular}{|c|}
$\mathrm{CO}_{2}$ \\
$(\mathrm{mg} / \mathrm{L})$
\end{tabular} & $\begin{array}{c}\mathrm{NH}_{4}^{+} \\
(\mathrm{mg} / \mathrm{L})\end{array}$ & \begin{tabular}{|c|}
$\mathrm{Mg}^{2+}$ \\
$(\mathrm{mg} / \mathrm{L})$
\end{tabular} & degree & $\mathrm{pH}$ & $\mathrm{SO}_{4}{ }^{2-}+\mathrm{Cl}^{-}\left(\mathrm{mg} / \mathrm{dm}^{3}\right)$ & $\begin{array}{c}\mathrm{CO}_{2} \\
(\mathrm{mg} / \mathrm{l})\end{array}$ & d \\
\hline $\mathrm{Ba}$ & Bald & 6.0 & 31.9 & 3.55 & 30 & 0 & 880 & 5.78 & $x 0$ & 30 & 98.5 & .00 & II \\
\hline Zbor & $\begin{array}{l}\text { ské } \\
\text { LZ) }\end{array}$ & 11.1 & 1269.9 & 20.04 & 8.25 & 0.00 & 0.025 & 12.16 & $\mathrm{X} 0$ & $\underline{8.25}$ & $\underline{20.04+11.1731 .21}$ & $\underline{0.00}$ & 1 \\
\hline D & ǎ̌i & 12.2 & 018 & 10.41 & 60 & 0 & & & $x_{0}$ & .60 & $\underline{10.41+}$ & .00 & 1 \\
\hline Číž & & 13.2 & 1206.3 & $\underline{310.56}$ & 1.90 & 0.00 & 0.025 & | & XA1 & $\underline{7.90}$ & $310.56+80.13390 .69$ & $\underline{0.00}$ & IV \\
\hline Rimavská Seč & Č́́ž (PLZ) & 14.2 & 1805.6 & 353.85 & 8.35 & 0.00 & 0.025 & 62.50 & XA1 & $\underline{8.35}$ & $353.85+113.44467 .29$ & $\underline{0.00}$ & IV \\
\hline Zádor & Z) & 15.0 & 469.5 & 18.05 & 3.10 & 0.00 & .025 & 47.91 & XA1 & 8.10 & $218.05+117.69335 .74$ & $\underline{0.00}$ & IV \\
\hline $\begin{array}{l}\text { Martin- } \\
\text { Záturčie }\end{array}$ & LZ) & 12.2 & 1030.9 & $\underline{523.55}$ & 8.00 & 0.00 & 0.025 & 30.38 & XA1 & $\underline{8.00}$ & 9.22 & $\underline{0.00}$ & IV \\
\hline Košúty & (PMZ) & 12.5 & 1363.2 & $\underline{209.12}$ & 8.25 & 0.00 & 0.025 & 119.9 & XA1 & 8.25 & $209.12+39.18 \quad 248.3$ & $\underline{0.00}$ & III \\
\hline Piešt’any, & Piešt’any (PLZ) & 12.8 & 1066.8 & 06.66 & 7.95 & .00 & .025 & 43.29 & XA1 & $\underline{7.9}$ & $206.66+63.11269 .77$ & 0.00 & III \\
\hline Slatina & Slatina (PMZ) & 10.3 & 1677.3 & $\underline{269.00}$ & 1.90 & 0.00 & 0.025 & 52.04 & XA1 & $\underline{7.90}$ & $269+126.2395 .2$ & $\underline{0.00}$ & IV \\
\hline Smrdáky & Smrdáky (PLZ) & 9.0 & 1089.7 & 163.32 & 7.95 & 0.00 & 0.025 & 53.26 & $\mathrm{X} 0$ & $\underline{7.95}$ & $163.32+79.07242 .39$ & $\underline{0.00}$ & III \\
\hline Tornal'a & Tornal'a (PMZ) & 12.8 & 1103.9 & 90.11 & .35 & 60 & .025 & 29.18 & XA1 & $\underline{7.35}$ & $290.11+153.14443 .25$ & 6.60 & IV \\
\hline \begin{tabular}{|c|}
$\begin{array}{c}\text { Trenčianske } \\
\text { Jastrabie }\end{array}$ \\
\end{tabular} & $\begin{array}{l}\text { Trenč. Mitice } \\
\text { (PMZ) }\end{array}$ & 9.7 & 1283.6 & $\underline{344.01}$ & 7.55 & 0.00 & 0.025 & 68.10 & XA1 & $\underline{7.55}$ & $344.01+22.87366 .88$ & $\underline{0.00}$ & IV \\
\hline
\end{tabular}

Remark: PLZ - natural healing source, PMZ - natural mineral source, $\mathrm{T}_{v}$ - water temperature, $\mathrm{M}$ - mineralization, degree - degree of chemical effect on concrete, aggressiveness of environment on metal constructions, respectively. 
Fig. 1 Aggressiveness of water in certified natural mineral and healing water sources.

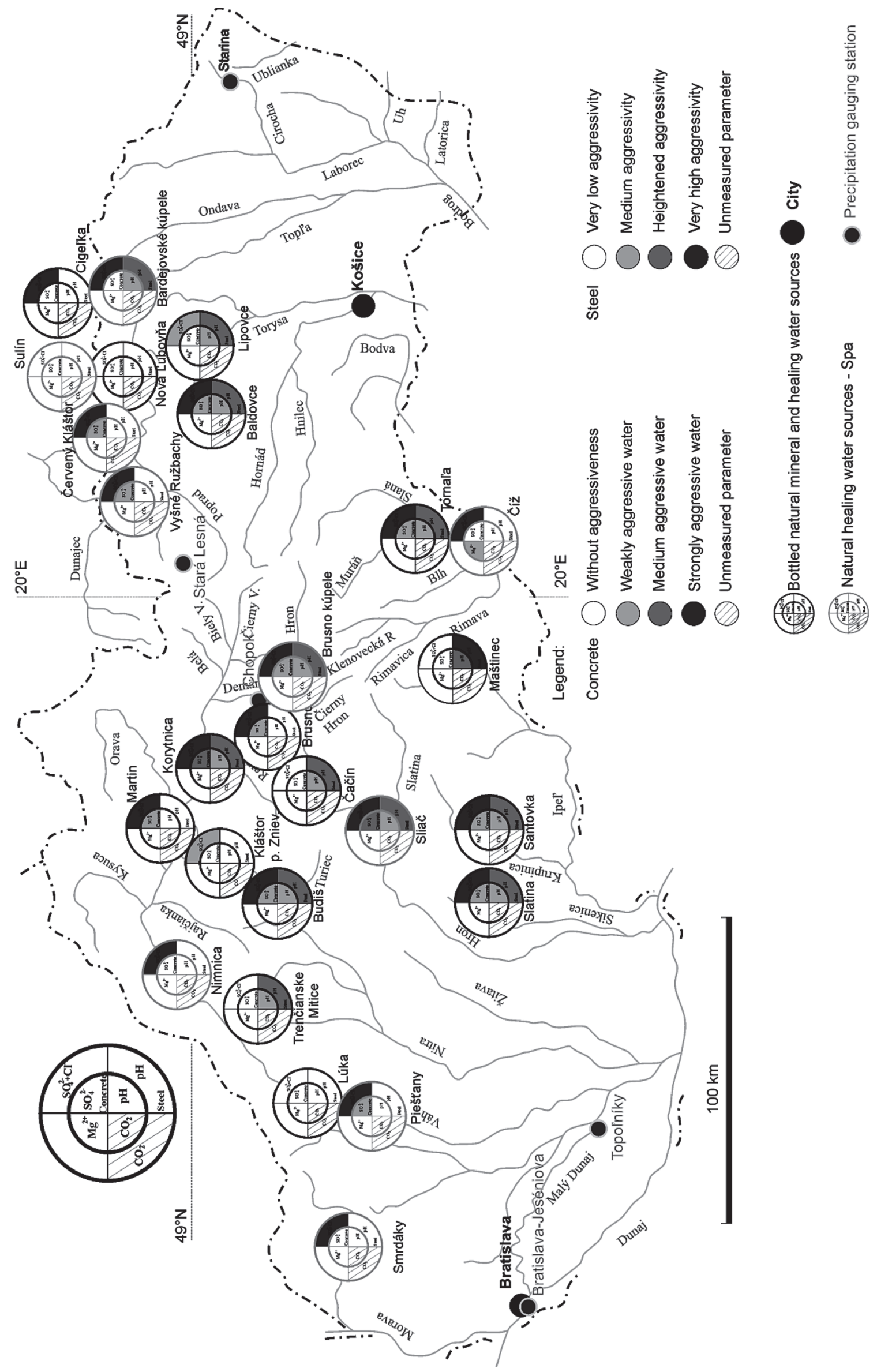


The natural healing waters were aggressive towards concrete in 16 sources. Nine of them are aggressive because of low $\mathrm{pH}$ values, ten because of the over-limit of sulfate concentrations, and one (Č́íz, BČ-5) because of the over-limit magnesium concentration. A combination of low $\mathrm{pH}$ values and increased sulphate concentrations occurred in one source in Brusno and in three sources in Sliač. The aggressiveness caused by over-limit concentrations of ammonium ions was not documented. The XA1 degree of aggressiveness prevailed, except for five sources (Sliač - Bystrica, Lenkey, Adam and Brusno - Ludvig and Dumbier), where the XA2 degree was estimated. Also in this case, all the evaluated natural healing waters are aggressive towards metals. Most of the sources have the highest (IV) degree of aggressiveness because of a low $\mathrm{pH}$ and a high total concentration of sulphates and chlorides.

The evaluation of the mineral springs located in the vicinity of certified mineral water and natural healing water sources showed that except for one locality (Tornal'a), none of them have aggressiveness caused by the presence of aggressive carbon dioxide.

The results showed that the disintegration of concrete building constructions could occur in most of the evaluated localities in the case of their contact with mineral water. The corrosion of wells tapping the mineral water and pipelines transporting it could also occur. Therefore, preventive measures are necessary. It is also necessary to prepare a new standard for an evaluation of aggressive water effects on metals.

\section{Acknowledgments}

This publication is the result of the implementation of the project: Comenius University in Bratislava Science Park supported by the Research and Development Operational Programme funded by the ERDF, grant No. ITMS 26240220086. 


\section{REFERENCES}

Fendek, M. - Bodiš, D. - Biely, A. - Kullmanová,A. - Gašparíková, V. - Snopková, P. - Král, M. - Jančí, J. (1988) Správa o výskumnom geotermálnom vrte ZGL-1 Bešeňová - overenie prognóz zdrojov geotermálnej energie Liptovskej kotliny - západ. (Research report on ZGL-1 geothermal well in Bešeñová - verification of the geothermal energy sources prognosis in Liptovska kotlina-west). Bratislava, Geological Survey of Slovak Republic, 85 pp. (in Slovak).

Fendek, M. (1998) Zachytenie geotermálnych vôd v Bešeňovej (Tapping of geothermal water in Bešeňová). Proceedings of the conference on Balneotechnické Days '98. Bratislava, Faculty of Civil Engineering, Slovak University of Technology in Bratislava, pp. 92-102 (in Slovak).

Fendek, M. - Poráziková, K. - Štefanovičová, D. - Supuková, M. (2002) Geothermal and mineral water sources Scale 1: 500000 Landscape Atlas of the Slovak Republic, 1st ed. Bratislava: Ministry of the Environment of the Slovak Republic; Banská Bystrica, Slovak Environmental Agency. pp. 214-215. ISBN 80-88833-27-2

Fendek, M. - Remšík, A. (2005) Hodnotenie množstva geotermálnej vody a geotermálnej energie Liptovskej kotliny (Evaluation of geothermal water and geothermal energy amounts of the Liptovská kotlina basin). Mineralia Slovaca, Vol. 37, No. 2, pp. 131136 (in Slovak).

Fendeková, M. - Malík, F. - Krčmářr, D. - Fendek, M. Roháčiková, A. (2011) Groundwater aggressiveness assessment according to EN 206-1: data, methods and application on groundwater in the Horna Nitra basin, Slovakia. Environmental Earth Sciences, Vol. 64, No. 2, pp. 461-470.

Hairston, J.E. (1995) Water quality and pollution control handbook. World Wide Web Address: http//www.aces.edu/pubs/docs/A/ ANR-0790/.

Hyánková, K. (1985) Agresívne vlastnosti podzemných vôd Slovenska (Aggressive properties of groundwater in Slovakia). Dissertation thesis, Prírodovedecká fakulta Univerzity Komenského v Bratislave, 1985, 158 pp. (in Slovak).
Rapant, S. - Bodiš, D. (1996) Geochemical Atlas of Slovakia, Groundwater part. Bratislava, Geological Survey of Slovakia, Dionyz Stur Publishers, 167 pp., ISBN 80-85314-67-3

Remšík, A. - Fendek, M. - Mad'ar, D. (2005) Výskyt a rozšírenie geotermálnych vôd $v$ Liptovskej kotline (Occurrence and spatial distribution of geothermal water in Liptovská kotlina basin). Mineralia Slovaca, Vol. 37, No. 2, pp. 123-130 (in Slovak).

Sander, A. - Berghult, B. - Elfstroem Broo, A. - Lin Johansson, B. - Hedberg, T. (1996) Iron corrosion in drinking water distribution systems - The effect of $\mathrm{pH}$, calcium and hydrogen carbonate. Corrosion Science, Vol. 38, No. 3, pp. 443-455.

Volk, Ch. - Dundore, E. - Schiermann, J. - LeChevallier, M. (2000) Practical evaluation of iron corrosion control in a drinking water distribution system. Water Research, Vol. 34, No. 6, pp. 1967-1974.

Act No. 538/2005 Z.z. o prírodných liečivých vodách, prírodných liečebných kúpeloch, kúpelných miestach a prírodných minerálnych vodách a o zmene a doplneni niektorých zákonov (on natural healing waters, natural healing spas and spa sites, and natural mineral waters and on change and complementation of some acts). Ministry of Health of the Slovak Republic (in Slovak).

STN EN 206-1 (STN 73 2403) (2002) Betón. Čast' 1: Špecifikácia, vlastnosti, výroba a zhoda (Concrete. Part 1: Specification, performance, production and conformity). Slovak Institute for Technical Normalisation, Bratislava, publication No. 85349, 72 pp.

STN 038375 (1986) Ochrana kovových potrubí uložených v půdě nebo ve vodě proti korozi (Corrosion protection of underground metallic pipelines). Adopted since 1.1.1993. Publishing house of the Institute for Normalisation and Measurement, Prague (in Czech). 